\title{
Application of Traffic Calming Devices in Developing Countries: Learning Lesson from Bangladesh
}

\author{
Farzana Rahman ${ }^{*}$, Tri Basuki Joewono ${ }^{2}$, Shahidullah Al Masum ${ }^{3}$ \\ ${ }^{1}$ Department of Civil Engineering, University of Asia Pacific, Dhaka, Bangladesh \\ ${ }^{2}$ Parahyangan Catholic University, Bandung, Indonesia \\ ${ }^{3}$ Military Institute of Science and Technology, Dhaka, Bangladesh \\ Email: *farzana-ce@uap-bd.edu,vtribas@unpar.ac.id,farzana_rahman2002@yahoo.com
}

How to cite this paper: Rahman, F., Joewono, T.B. and Al Masum, S. (2018) Application of Traffic Calming Devices in Developing Countries: Learning Lesson from Bangladesh. Journal of Transportation Technologies, 8, 119-135. https://doi.org/10.4236/jtts.2018.82007

Received: October 22, 2017

Accepted: April 15, 2018

Published: April 18, 2018

Copyright ( 92018 by authors and Scientific Research Publishing Inc. This work is licensed under the Creative Commons Attribution-NonCommercial International License (CC BY-NC 4.0). http://creativecommons.org/licenses/by-nc/4.0/ (c) (i) \& Open Access

\begin{abstract}
Traffic calming devices become more favorable for many cities to manage traffic in urban as well as neighborhood areas. Many developing cities already initiated the implementation, while the process has a wide variation in both quality and quantity. The objective of this study is to evaluate the justification of speed humps in urban roads and also to recommend a guideline for installation of speed humps as a traffic calming device in Dhaka city, Bangladesh. It was found that there are vast variations in the implementation, while general public also express an immense disparity of perception about devices quality and suitability and their agreement. Lesson learned from Dhaka City shows that selecting an appropriate placement and dimension of the traffic humps is an urgent requirement to be solved by government by providing standards, guidelines, and policy when there is an initiative to implement or improve traffic calming application.
\end{abstract}

\section{Keywords}

Traffic Calming, Policy, Guideline, Lesson Learned, Developing Countries

\section{Introduction}

Bangladesh, a country having population of 142 million, has about 1.5 million motorized and could be over 3 million non-motorized vehicles [1]. The number of vehicles is increasing remarkably in recent years as the population is increasing extremely in Dhaka city. Bangladesh has a very high fatality rate in road accidents-more than eighty five deaths per ten thousand registered motor ve- 
hicles per year, where in Dhaka City only, 2720 accidents caused a total of 1481 numbers of pedestrian fatal accidents with 1562 pedestrian fatal casualties during 2007-2011 [2].

Several measures might be implemented to reduce fatal accidents, where one of them is reducing vehicle speed. Pasanen [3] and Anderson et al. [4] determined that reducing vehicle speeds would have reduced pedestrian injuries in two ways, namely by eliminating some crashes altogether and by reducing injury severities in the others. Speed management approaches that include traffic engineering methods are often called traffic calming. Lockwood [5] [6] defines that traffic calming is the combination of mainly physical measures that reduce the negative effects of motor vehicle use, alter driver behavior, and improve conditions for non-motorized street users. Neighborhood traffic calming measures are an attempt to enhance traffic and pedestrian safety and to preserve neighborhood character and livability [7]. Ewing et al. [8] found that traffic calming becomes mainstream programs, receives less apparent public controversy receives greater reliance on private financing of construction, receives more public participation, and limited expansion of eligibility to include arterials. Traffic calming includes a variety of measures to slow motor vehicles and make room for bicycles and pedestrians, which includes such as speed bumps, curb extensions, raised crosswalks, chicanes, roundabouts, gateways and entry treatments as well as other interventions.

It is also argued that the reduction of traffic volume or speed using traffic calming is a mean to other ends, such as improving the quality of life in residential areas and all parts of the community, increasing walking safety in commercial areas, or making bicycling more comfortable on collectors routes. Thus, it can be inferred that traffic calming is attempted to ensure calm, safe, and environmentally improved conditions on streets. More recently, however, traffic calming devices have been proposed for some major commuting corridors to impede traffic flow, thereby encouraging motorists to choose other routes or other means of transportation [9]. Traffic calming can slow vehicular traffic very effectively. Changes in speed have been shown to be related to changes in injury accidents, with a $1 \mathrm{mph}$ reduction in mean speed giving a 5\% reduction in accident frequency [10].

Study about traffic calming was mainly conducted in developed countries, i.e. European, North America, or Japan by Rahman et al. [11]. Small number of studies was conducted in developing countries, e.g. Joewono et al. [12] conducted study in Bandung, Indonesia, Hydén and Svensson [13] in Jaipur, India, or Rosli and Kadar Hamsa [14] in Kuala Lumpur, Malaysia. It is argued that the characteristics of the implementation of traffic calming in developing countries are significantly different as a result of mixed traffic, vast variety of drivers and motorcyclist behavior, and unstandardized road infrastructure. Thus, a study about traffic calming in developing cities, likes Dhaka in Bangladesh, will be beneficial.

As a matter of fact, speed hump or speed bump are the most common devises 
used in places in Dhaka city, besides the application of rumble stripe used in highways. At present, in Bangladesh still there is not available national policies and design guidelines of traffic calming devices yet. It results in variation of dimension, placement, or type of additional facilities. Thus, speed hump is also found erroneous from different point of view like dimension, placement, or additional warning signs. In the other side, there is a need for effective measures to reduce or maintain safe travel speeds within neighborhoods and dense pedestrian traffic areas.

The objective of this study is to evaluate the justification of speed humps in urban roads and also to recommend a guideline for installation of speed humps as a traffic calming device in Dhaka city, Bangladesh. The scope of this study covers several aspects, such as existing situation of traffic calming device in Bangladesh, guidelines used presently, irregularities in installation process, problems of traffic calming devices, and requirement of revision of policy and guidelines. A lesson learned from the experience of the application in Dhaka City will be useful for other developing cities, especially in Asian countries.

\section{Traffic Calming Practices in Bangladesh}

\subsection{Traffic Calming Standards}

Traffic calming devices should be installed only in conformance to the established design criteria, in effect at the time of their installation, and if all of the justification criteria are met. Study by Rahman et al. [11] reveals that most cities in North American are having a warrant based system to check the suitability of traffic calming device. It was found that the budget constraint is the most important reason to prioritize traffic calming projects while political intervention is the main drawback of the process. If it meets all of the justification criteria, then it will be rated and prioritized according to other criteria, such as traffic volume, speed, accidents, and petitions [9]. As with any traffic calming device, additions, alterations, or removal of any or all traffic calming devices may occur at any time if conditions warrant. In fact, the application of traffic calming could be vary among places. A technical resource developed by James et al. [15] is an example of guidance for the development of traffic calming programs, which compiled the do's and don'ts of traffic calming. Kojima et al. [16] found the effective speed hump installment by considering vehicle speed, noise, and vibration as well as roadside installment.

As an example, in the United States, although the Federal Highway Administration specifies standards and guidelines through the MUTCD, individual state and local agencies can provide variations or additions to these standards [17]. Another example comes from Asia. Indonesia has speed hump standard as well, while in fact, this standard was not fully implemented by community. This standard was developed by Departemen Pemukiman dan Prasarana Wilayah [18], where it was adopted from UK Department of Transport.

Based on these facts, it was difficult to formulate definitive conclusion about 
the effectiveness of traffic calming devices [19]. In practice, there had been few problems which originated from traffic calming devices [20], like emergency response concerns, violate civil rights such as segregate communities along racial and socio-economic lines, violation to clean air act as a result of fact that the project of humps increased emissions, complaints from the disabled community, and possibility of conflict among communities.

\subsection{Practices in Bangladesh}

At present, the capital city Dhaka is the most claimed traffic congestion city in Bangladesh, since in general; Bangladesh doesn't meet the required transportation facility as well as transportation safety for the citizens [21]. Traffic calming in Bangladesh illustrates a range of practices, such as speed hump, speed table, choker, chicane, pavement marking, or textured and colored pavement. Even though, traffic calming warrants must be met before implementation of traffic calming devices but no set guidelines and criteria was found in Bangladesh at present.

Over the last few years, increasing number of motorized vehicles, vast population, and insufficient budget for the improvement of transportation facility and neighborhood safety have approached the country with issues of speeding and cut-through traffic. Historically, these situations could only be addressed by the use of police enforcement or speed humps. An expanded menu of options was required to address these issues. Requests for utilizations of traffic calming measures have been proved to be effective enough to manage the intolerable congestion of Dhaka city as well as the whole Bangladesh to meet the present traffic issues.

Presently in Bangladesh, few agencies are working on road safety, though there is very little practice observed in case of Traffic Calming. Traffic calming regulations are required to provide local highway authorities with the necessary powers to construct speed reduction and other measures for traffic calming that are not otherwise clearly authorized. Provision may need to be left for detailed specifications via ministerial regulations.

National Road Safety Strategic Action Plan 2011-2013 is the $6^{\text {th }}$ plan in Bangladesh [1], where the first road safety action plan for Bangladesh (1997-1999) was approved on 1st February, 1997. There are nine individual sectors identified for road safety activities: National road safety council, Accident data system, Road engineering, Traffic legislation, Traffic enforcement, Driver training and testing, Vehicle safety, Education and publicity, and Medical services. Planning, management, and coordination of road safety is planned to be done by a specified framework as appears in Table 1. Road Safety Division of RHD (Roads and Highway Department) is responsible for permission of installation of a new Traffic Calming Device, while NRSC (National Road Safety Council) involved with decision making process of Traffic Calming Device. BRTC works to research on safety considerations for bringing harmony in the operation of 
Table 1. Framework for planning, management, and coordination of road safety (Ministry of Communications [6]).

\begin{tabular}{|c|c|c|}
\hline No. & Sub-sectors & Agency responsible \\
\hline 01. & $\begin{array}{l}\text { Bangladesh Road Transport } \\
\text { Authority } \\
\text { (Organization and Staffing) }\end{array}$ & $\begin{array}{l}\text { NRSC (National Road Safety Council); BRTA } \\
\text { (Bangladesh Road Transport Authority); ARI } \\
\text { (Accident Research Institute), BUET (Bangladesh } \\
\text { University of Engineering \& Technology) }\end{array}$ \\
\hline 02. & $\begin{array}{l}\text { Road Safety Organizations } \\
\text { and Committees }\end{array}$ & $\begin{array}{l}\text { MRSCs (Metropolitan Road Safety Committees), } \\
\text { DRSCs (District Road Safety Committees), URSCs } \\
\text { (Upzilla Road Safety Committees) }\end{array}$ \\
\hline 03. & Finance & All concern ministries \\
\hline 04. & Strategic Development & $\begin{array}{l}\text { BRTA (Bangladesh Road Transport Authority); RHD } \\
\text { (Roads and Highway Department); LGED (Local } \\
\text { Government Engineering Department); MOC (Ministry } \\
\text { of Communications); ARI (Accident Research } \\
\text { Institute), BUET (Bangladesh University of } \\
\text { Engineering \& Technology) }\end{array}$ \\
\hline
\end{tabular}

bus and truck services. Inclusion of road safety component in all important road projects of RHD and LGED (Local Government Engineering Department) is a part of strategic development plan. ARI (Accident Research Institute), BUET (Bangladesh University of Engineering \& Technology) works on Development of a multimodal safe transport system in Bangladesh through Education, Research, Training Investigation, and Consultation. Research and investigation to identify the accident contributory factors and their remedial measures among which Traffic Calming Device are some of the major components. MOC (Ministry of Communications) is fully responsible for supervision of all the activities of these agencies.

In Bangladesh, the concept of traffic calming devices is not very widely used. It is not very much practiced in the neighborhood in Dhaka city and other part of the country. Thus, it has very low impact in Bangladesh. Speed hump or speed bump are the most common devises used in places in Dhaka city, besides the application of rumble strip used in highways. At present, in Bangladesh still there is not available national policies and design guidelines of traffic calming devices yet. It is argued that many other types of traffic calming measures could be tried to be implemented to increase the traffic safety in the neighborhood. It is also believed that now is the time to formulate a plan and set a national policy to make the neighborhood safer and reduce the risk of accident among the city roads and streets.

Lack of standard or guideline about traffic calming results in several problems. It is argued that the main concept of placing Rumble Strip was to attract attention of the driver so that the vibrating due to rumble strip reminds the driver that she/he needs to drive carefully. It is necessary in some places of the highway where pedestrian crossing rate is high due to the presence of school, college, or markets. But, many people requested to remove the rumble strips and replace it 
by other means like foot over bridge. It happened as there is no set guideline or criteria nationwide.

\section{Method}

This study was carried out in two phases. The first phase was field survey and the second one was questionnaire survey. The first phase was conducted by a thorough field survey in different major arterials, distributor, and local roads of Dhaka city to collect field data of existing cross sectional dimensions of traffic calming device. Data were collected on day time and measurement of the dimension of the devices was taken physically. Suitability of the devices was considered on the basis of pedestrian generation and traffic volume. Photographs of the devices were also taken. This phase was followed by a pilot questionnaire survey in Military Institute of Science and Technology, Mirpur, Dhaka on $5^{\text {th }}$ October 2011. Then, a through questionnaire survey was carried out from $6^{\text {th }}$ October up to $3^{\text {rd }}$ December 2011 in the selected survey locations. This survey intended to know the different requirement of the traffic calming devices from the users of different professions and classes. Sincere efforts were taken to know the recommendations and demand of the respondents of the area about the traffic calming device. In this study, seven locations are selected and the detail information is provided in Table 2.

Data was collected in a convenient manner, which is not fully random in nature, according to the availability of the respondent. To obtain a clear picture, a total of three categories of roads like Arterial, Distributor, and Local road were selected. Motijheel-Farmgate-Uttara road was selected as arterial data collection segment, Mirpur-1-Mirpur-10-Kafrul road as distributor data collection segment, and Mirpur-6-Mirpur-7-Mirpur-11.5 as local road data collection segment. As recently one accident took place near Monipur School in Shewrapara area and one speed hump was installed immediately so a single point survey in that place was conducted. Total twelve points on arterial road, five points on distributor, and eleven points on local road were selected. Data was collected from different locations of Dhaka city with a view to compare the different information regarding speed hump. Duration of field survey was two weeks. All the group members have collected data in a segmented manner.

\section{Data and Analysis}

\subsection{Findings from Field Survey}

Three types of road in Dhaka city are considered, where the locations are Mirpur-1, Kazipara, Mirpur-7, Mirpur-11.5, Mirpur-12, Mirpur-14, Manik Mia Avenue, or New Airport Road. These sites are selected based on population density, number of vehicle movement, or pedestrian generation. Results of survey are presented in Table 3, while Figure 1 shows variation of speed hump in the field.

There is no distinct Government policy and also no set guide lines with the 
Table 2. Detail of survey location.

\begin{tabular}{|c|c|c|}
\hline No. & Name & Description \\
\hline 1 & Mirpur Section-1 & $\begin{array}{l}\text { It is an intersection which connects three major important } \\
\text { arterials (Mirpur-1 to Technical, Mirpur-1 to Mirpur-10. It is an } \\
\text { important place because pedestrian generation is quite high, } \\
\text { where the sources are office workers, labors, garment workers, } \\
\text { students from various classes. Few garments, offices, school and } \\
\text { colleges, hospitals and clinics are situated in this location which } \\
\text { generates high volume of pedestrian. }\end{array}$ \\
\hline 2 & Mirpur Section-10 & $\begin{array}{l}\text { It is an intersection which connects four major important } \\
\text { arterials (Mirpur-10 to Agargaon, Mirpur-10 to Mirpur-1, } \\
\text { Mirpur-10 to Mirpur-12, Mirpur-10 to Dhaka Cantonment). } \\
\text { It is an important place because pedestrian generation is too high. } \\
\text { Sources of pedestrian generation are office workers, labors, } \\
\text { garment workers, students from various classes }\end{array}$ \\
\hline 3 & Mirpur Section-14 & $\begin{array}{l}\text { It is an intersection which connects three major important } \\
\text { arterials (Mirpur-14 to Mirpur-10, Mirpur-14 to Kachukhet, } \\
\text { Mirpur-14 to Vashantek). It is an important place because } \\
\text { pedestrian generation is very high. Sources of pedestrian } \\
\text { generation are dental college, schools, or madrasa. }\end{array}$ \\
\hline 4 & $\begin{array}{l}\text { Near Osmani Hall In } \\
\text { Mirpur Cantonment }\end{array}$ & $\begin{array}{l}\text { It is one of the entrances to the cantonment and Defense Service } \\
\text { Command and Staff College. A large number of pedestrian } \\
\text { generated from residential building POLASH, SHAPLA. Also } \\
\text { OSMANI HALL is another source of pedestrian generation. }\end{array}$ \\
\hline 5 & $\begin{array}{l}\text { Mirpur-11 junction } \\
\text { near Yantai Chinese }\end{array}$ & $\begin{array}{l}\text { It is an intersection which connects three major important roads } \\
\text { (Mirpur-11 to Mirpur-10, Mirpur-11 to Mirpur-12, Mirpur-11 to } \\
\text { Mirpur-2, This location connect local road with collector roads. } \\
\text { No heavy vehicle moves on these roads. Pedestrian usage of this } \\
\text { road is high. }\end{array}$ \\
\hline $6 \& 7$ & $\begin{array}{l}\text { Air Port Road and } \\
\text { Manik Mia Avenue }\end{array}$ & $\begin{array}{l}\text { Air Port Road and Manik Mia Avenue are the two major Arterial } \\
\text { roads. These two venues were found to be the most favorite } \\
\text { places for speed racing for some of the users. Later on these two } \\
\text { roads meet the following reason to be installed with Traffic } \\
\text { calming devices, i.e.: } \\
\text { a) Reasons for selecting Airport Road; 1) No existing U Turn } \\
\text { facility except Right turn and 2) Existence of some important } \\
\text { mass communicating installations in the roadside neighborhood } \\
\text { like Radisson Water garden hotel, Army stadium, Army } \\
\text { headquarter, Navy Headquarter } \\
\text { b) Reasons for selecting Manic Mea Avenue; 1) To provide tres- } \\
\text { passing facility from National Assembly Hall to NAM } \\
\text { buildings, 2) To provide a safe flow for the holiday eve enjoying } \\
\text { people, and 3) To ensure road safety to the mass assembling } \\
\text { people. }\end{array}$ \\
\hline
\end{tabular}

concern authority to implement traffic calming devices, as well as to evaluate the sensitivity of the standard, justification, and appropriateness of the devices. It was found that due to lack of knowledge regarding the strengths and shortcomings of traffic calming devices, neighbor is less sensitive to the standard, justification and appropriateness of the Traffic Calming Devices. The situation is explained by the variety of dimensions of the devices as appears in Figure 2, Figure 3, and 
Table 3. Results of survey at banani-airport arterial road.

\begin{tabular}{|c|c|c|c|c|c|}
\hline $\begin{array}{c}\text { Serial } \\
\text { Number }\end{array}$ & $\begin{array}{l}\text { Location of } \\
\text { The Device }\end{array}$ & $\begin{array}{l}\text { Height of } \\
\text { Speed } \\
\text { Hump (in.) }\end{array}$ & $\begin{array}{l}\text { Width of } \\
\text { Speed } \\
\text { Hump (in.) }\end{array}$ & $\begin{array}{c}\text { Roadway } \\
\text { Width per } 2 \\
\text { Lane-2Way }(\mathrm{ft})\end{array}$ & $\begin{array}{l}\text { Sources of Pedestrian } \\
\text { Generation }\end{array}$ \\
\hline 1 & $\begin{array}{c}\text { Before } \\
\text { Radisson Hotel }\end{array}$ & 6 & 132 & 40 & $\begin{array}{l}\text { Cantonment Rail Station, } \\
\text { Radisson Hotel, Armed } \\
\text { Forces Medical College }\end{array}$ \\
\hline 2 & $\begin{array}{l}\text { Before Mess A, } \\
\text { Staff Road }\end{array}$ & 6 & 130 & 40 & $\begin{array}{l}\text { Zia colony, Mess A, } \\
\text { Engineer Brigade, } \\
\text { Baridhara DOHS }\end{array}$ \\
\hline 3 & $\begin{array}{l}\text { Beside Kabab } \\
\text { Ghor, Army } \\
\text { Stadium }\end{array}$ & 5 & 55 & 40 & $\begin{array}{l}\text { Army Stadium, Kabab } \\
\text { Ghor, Officers quarter, } \\
\text { ASPTS, BOF }\end{array}$ \\
\hline 4 & $\begin{array}{l}\text { Before Navy } \\
\text { Head Quarter }\end{array}$ & 6 & 121 & 35 & $\begin{array}{l}\text { Navy Head Quarter, } \\
\text { Bonani Officers Quarter, } \\
\text { Army Stadium }\end{array}$ \\
\hline 5 & $\begin{array}{l}\text { Before Navy } \\
\text { Head Quarter } \\
\text { (Approach } \\
\text { From Kakoli } \\
\text { To Airport) }\end{array}$ & 3 & 39 & 35 & $\begin{array}{l}\text { Army Head Quarter } \\
\text { Bypass Road, Navy Head } \\
\text { Quarter, Bonani Officers } \\
\text { Quarter }\end{array}$ \\
\hline 6 & $\begin{array}{l}\text { Opposite To } \\
\text { Kabab Ghor } \\
\text { Army Stadium }\end{array}$ & 3.5 & 44 & 35 & $\begin{array}{l}\text { Army Stadium, Kabab } \\
\text { Ghor, Officers quarter, } \\
\text { ASPTS, BOF }\end{array}$ \\
\hline 7 & $\begin{array}{l}\text { Opposite To } \\
\text { Mess A }\end{array}$ & 6 & 155 & 35 & $\begin{array}{l}\text { Zia colony, Mess A, } \\
\text { Engineer Brigade, } \\
\text { Baridhara DOHS }\end{array}$ \\
\hline
\end{tabular}

Figure 4. As Dhaka City is running out of its capability in case of infrastructure to support its population, the in situ need to meet the local necessity overrules the evaluation of the justification and appropriateness of the devices. The result of interview survey with different government organization tells that there is no set procedure to guide the implementation of traffic calming device in Bangladesh. The current practice was guided only by the concerned of road construction authority.

\subsection{Findings from Questionnaire Survey}

From questionnaire survey, it was found that there are a vast variations in the response from the point of view of respondent. Variation is also detected for different types of road. The comparison results are provided in Table 4. For the question which deals with the suitability of the placement of the traffic calming device at distribution road, $56 \%$ of respondents state their agreement. High proportion $(86 \%)$ of the respondents state that the devices are suitable in arterial road, while on the contrary, $89 \%$ of respondents state their disagreement of the placement in local road.

From Table 4, it can be shown that users who used arterial road seem to be more familiar with the dimension of the measures. On the contrary, users in 


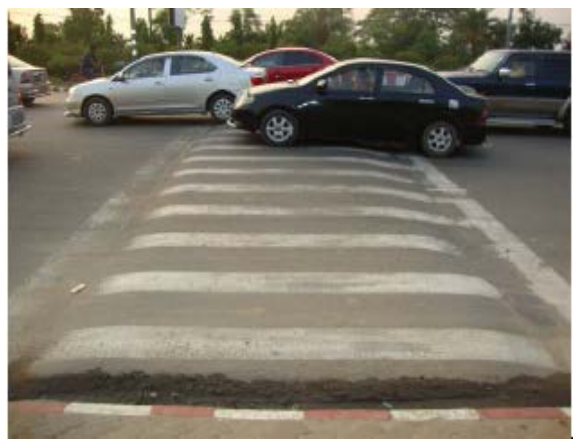

(a)

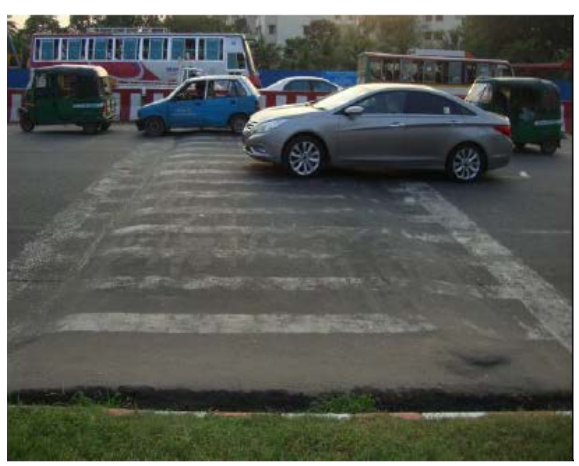

(c)

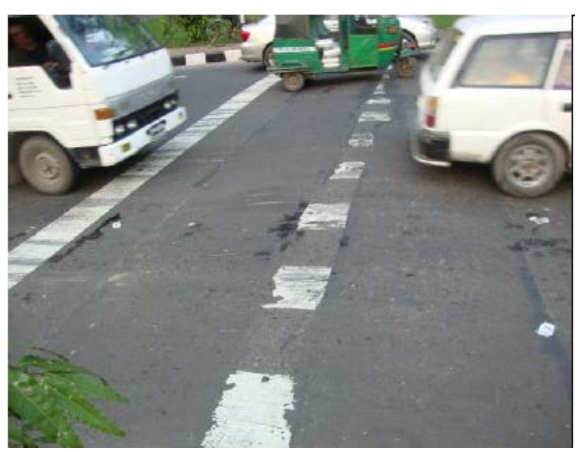

(e)

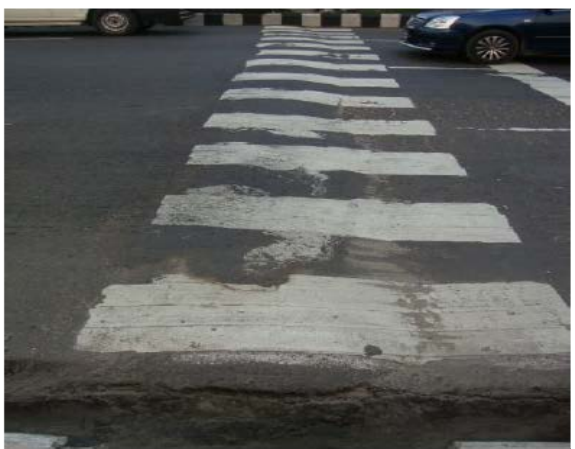

(g)

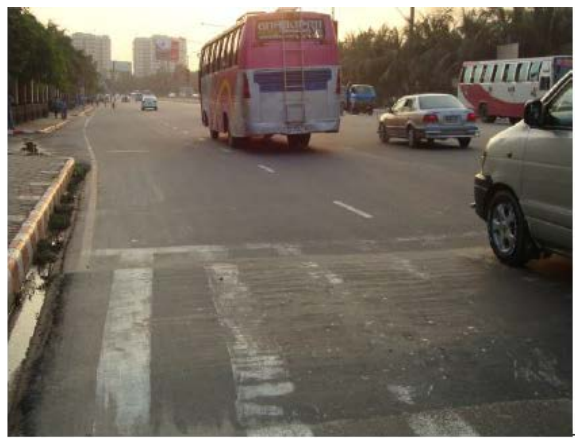

(b)

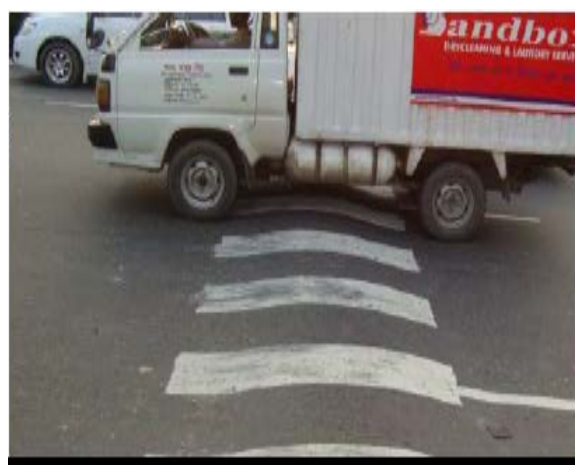

(d)

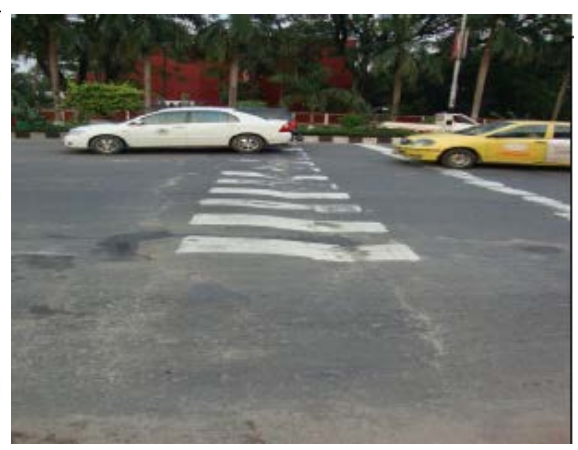

(f)

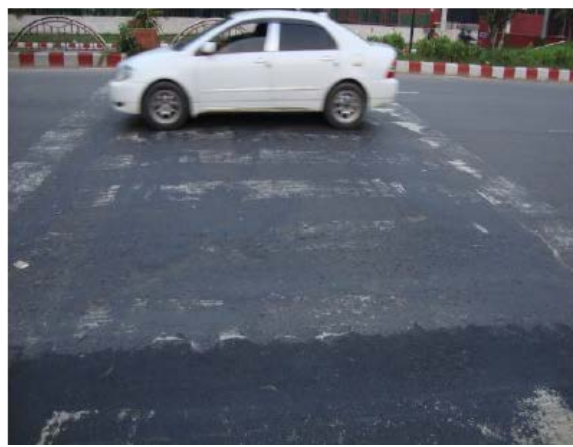

(h)

Figure 1. Various type of traffic calming. (a) Speed hump before Baridhara DOHS; (b) Speed hump near Hotel Radisson; (c) Before mess-a, dhaka cantonment; (d) Beside kabab ghor, army stadium dhaka; (e) Beside navy head quarter; (f) Opposite to navy headquarter; (g) Opposite to kabab ghor, army stadium; (h) Opposite to mess-a, dhaka cantt, staff road. 


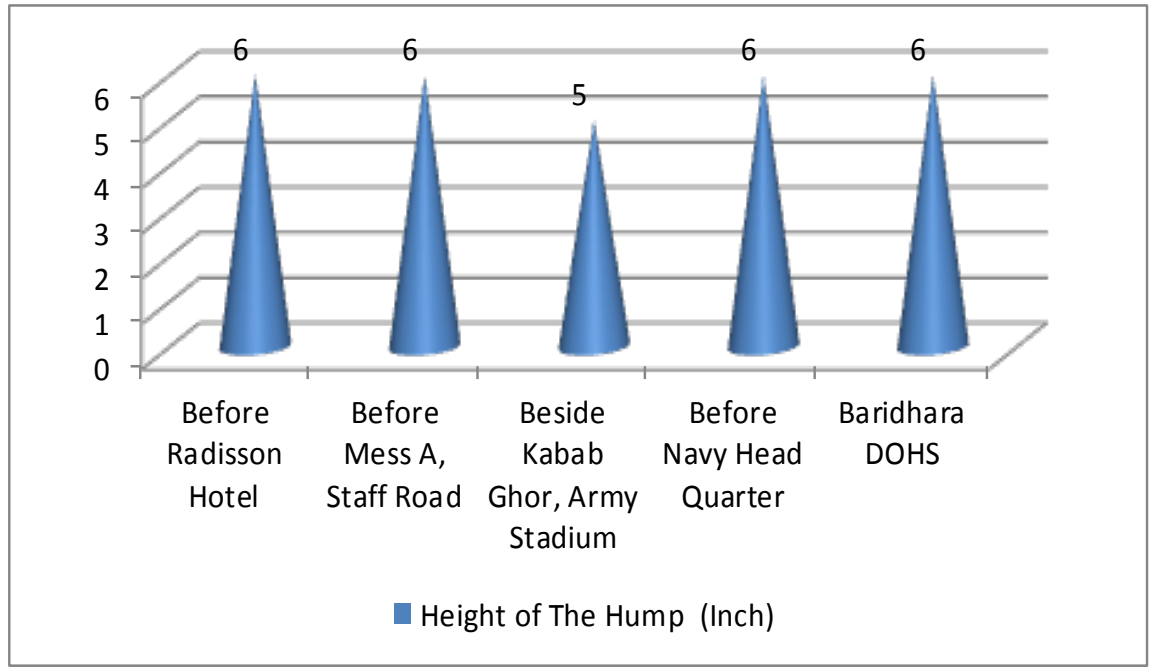

Figure 2. Comparison of the hump height at arterial road.

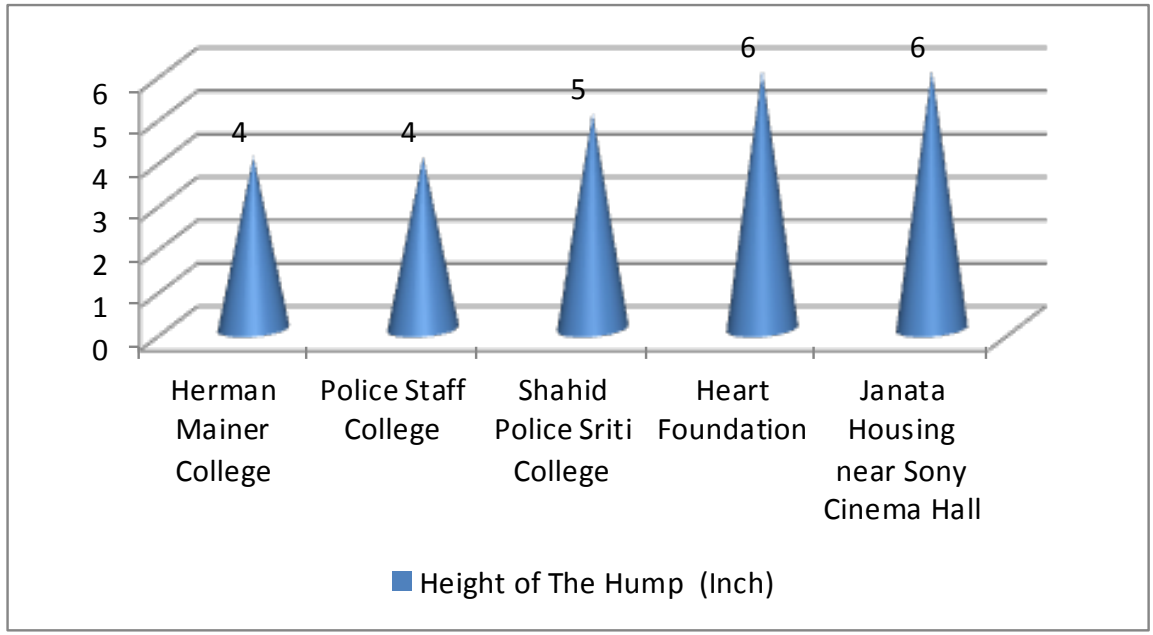

Figure 3. Comparison of the hump height at distributor road.

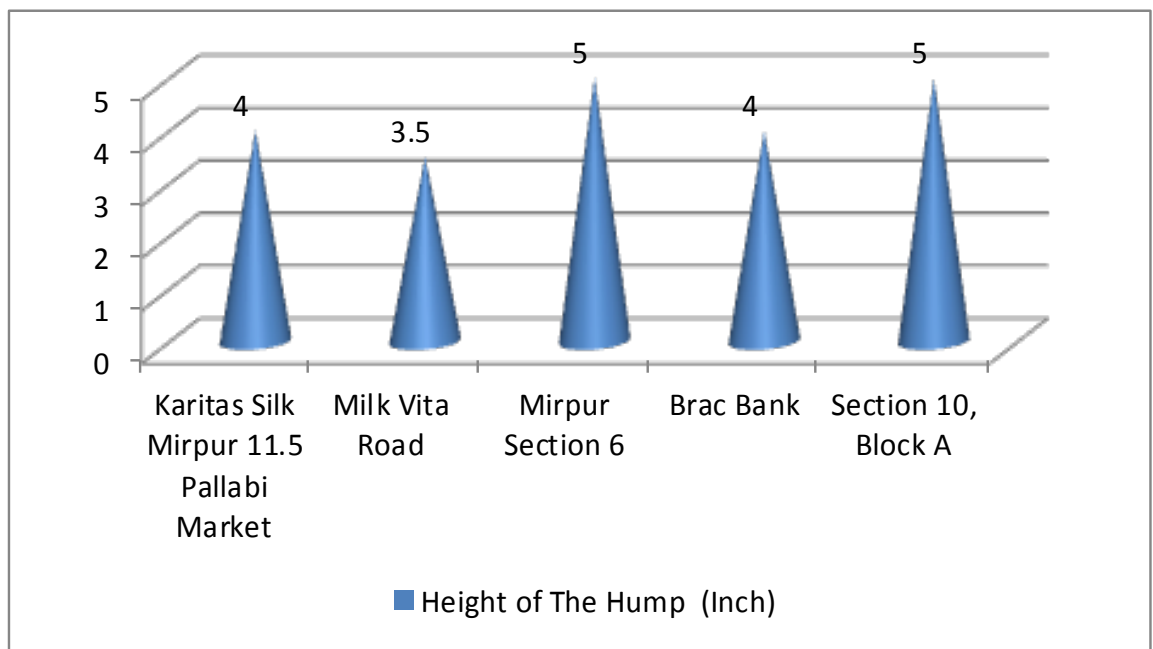

Figure 4. Comparison of the hump height at local road. 
Table 4. Comparisons of respondents' perception.

\begin{tabular}{|c|c|c|c|c|c|c|}
\hline \multirow[b]{2}{*}{ Aspects } & \multirow[b]{2}{*}{ Road classification } & \multicolumn{5}{|c|}{ Proportion (\%) } \\
\hline & & $\begin{array}{l}\text { Very } \\
\text { much }\end{array}$ & $\begin{array}{l}\text { Some } \\
\text { what }\end{array}$ & $\begin{array}{l}\text { Not so } \\
\text { much }\end{array}$ & Not at all & $\begin{array}{c}\text { No } \\
\text { comment }\end{array}$ \\
\hline \multirow{5}{*}{$\begin{array}{l}\text { the user friendliness of the } \\
\text { dimension of the traffic } \\
\text { calming device in }\end{array}$} & Arterial & 19 & 52 & 27 & 0 & 2 \\
\hline & Distributor & 6 & 9 & 18 & 51 & 16 \\
\hline & Local & 0 & 6 & 61 & 33 & 0 \\
\hline & & \multicolumn{5}{|c|}{ Proportion (\%) } \\
\hline & Road classification & Noise & Vibration & Air & $\begin{array}{l}\text { Acc. of } \\
\text { waste } \\
\text { material }\end{array}$ & All \\
\hline \multirow{5}{*}{$\begin{array}{l}\text { the environmental effect } \\
\text { of the traffic calming } \\
\text { device }\end{array}$} & Arterial & 43 & 25 & 14 & 12 & 6 \\
\hline & Distributor & 39 & 18 & 32 & 3 & 8 \\
\hline & Local & 29 & 57 & 0 & 0 & 14 \\
\hline & & \multicolumn{5}{|c|}{ Proportion (\%) } \\
\hline & Road classification & $\begin{array}{c}\text { Very } \\
\text { severe }\end{array}$ & $\begin{array}{l}\text { A bit } \\
\text { severe }\end{array}$ & severe & $\begin{array}{l}\text { Not very } \\
\text { severe }\end{array}$ & $\begin{array}{l}\text { No conges- } \\
\text { tion }\end{array}$ \\
\hline \multirow{5}{*}{$\begin{array}{l}\text { the congestion due to the } \\
\text { traffic calming device }\end{array}$} & Arterial & 4 & 14 & 35 & 41 & 6 \\
\hline & Distributor & 6 & 9 & 18 & 51 & 16 \\
\hline & Local & 0 & 1 & 35 & 41 & 23 \\
\hline & \multirow{2}{*}{ Road classification } & \multicolumn{5}{|c|}{ Proportion (\%) } \\
\hline & & \multicolumn{3}{|c|}{ Yes } & \multicolumn{2}{|l|}{ No } \\
\hline \multirow{3}{*}{$\begin{array}{l}\text { the fuel consumption due } \\
\text { to the traffic calming } \\
\text { device }\end{array}$} & Arterial & \multicolumn{3}{|c|}{39} & \multicolumn{2}{|l|}{61} \\
\hline & Distributor & \multicolumn{3}{|c|}{55} & \multicolumn{2}{|l|}{45} \\
\hline & Local & \multicolumn{3}{|c|}{15} & \multicolumn{2}{|l|}{85} \\
\hline
\end{tabular}

distributor or local seem as not familiar with the dimension. Users express that noise and vibration are the most problematic matters with the implementation of traffic calming. This exists in all road classification. It is interesting to know that users in all road classification state that the measures produce congestion as mild. Respondents seem to be in agreement that the implementation of traffic calming did not consume higher fuel.

\subsection{Model Estimation}

Binary logistic regression was employed to reveal the residents compliance about traffic calming device and the reasons behind. The dependent variable of the model is the resident's opinion about the suitability of placement of traffic calming device, where the value of one represents agreement for suitability and zero vice versa. Parameter estimates are described in Table 5.

The chi squared of the model has very small $p$-value, i.e. much lower than 0.05 , which means the independent variables play a significant role in the decision of the suitable placement of the traffic calming device. The significance ( $p$-value) of Hosmer Lemeshow test is much bigger than 0.05 , which means the 
Table 5. Binary logistic regression model.

\begin{tabular}{|c|c|c|c|c|}
\hline Variables & Coefficient & S.E & $\operatorname{Exp}(B)$ & Sig \\
\hline $\begin{array}{l}\text { Environmental pollution caused by this traffic } \\
\text { calming devices }\end{array}$ & 0.057 & 0.319 & 1.059 & 0.857 \\
\hline $\begin{array}{l}\text { Experience of any damage due to this traffic } \\
\text { calming device }\end{array}$ & -0.560 & 0.432 & 0.571 & 0.195 \\
\hline $\begin{array}{l}\text { Any traffic accident caused by these traffic } \\
\text { calming device }\end{array}$ & 0.029 & 0.334 & 1.029 & 0.932 \\
\hline $\begin{array}{l}\text { Traffic Calming Devices cause extra fuel } \\
\text { consumption for vehicle }\end{array}$ & 0.214 & 0.339 & 1.239 & 0.527 \\
\hline Alternative solution of this traffic calming device & 0.609 & 0.352 & 1.839 & 0.083 \\
\hline $\begin{array}{l}\text { Dimension of traffic calming device is very much } \\
\text { user friendly }\end{array}$ & 1.777 & 0.802 & 5.913 & 0.027 \\
\hline Opinion about the congestion in the area & -0.769 & 0.907 & 0.464 & 0.397 \\
\hline $\begin{array}{l}\text { Dimension of traffic calming device is not so } \\
\text { much user friendly }\end{array}$ & -1.223 & 0.335 & 0.294 & 0.000 \\
\hline $\begin{array}{l}\text { Dimension of traffic calming device is not at all } \\
\text { user friendly }\end{array}$ & -1.787 & 0.413 & 0.168 & 0.000 \\
\hline $\begin{array}{l}\text { No comment about the dimension of traffic } \\
\text { calming device }\end{array}$ & -0.587 & 1.380 & 0.556 & 0.670 \\
\hline $\begin{array}{l}\text { Reasons for considering traffic calming device a } \\
\text { threat }\end{array}$ & -2.367 & 1.827 & 0.094 & 0.195 \\
\hline Problems facing from this traffic calming device & 0.804 & 0.327 & 2.234 & 0.014 \\
\hline Gender $[1=$ male, 0 otherwise $]$ & -0.364 & 0.317 & 0.695 & 0.252 \\
\hline Opinion about a bit severe congestion & 1.057 & 0.529 & 2.877 & 0.046 \\
\hline Own a personal vehicle (car, motor cycle) & -0.024 & 0.381 & 0.976 & 0.949 \\
\hline Constant & 0.554 & 0.439 & 1.740 & 0.207 \\
\hline
\end{tabular}

failure to reject the null hypothesis that there is no difference between observed and model predicted values. This statistics imply that the model's estimates fit the data at an acceptable level. The percentage has a value of $74.7 \%$, which implies a good fitting model. Thus, it can be inferred that the model is well fitting.

The model found several significant variables, namely the dimension of traffic calming devices, comfort in using devices and smoothness in riding. It can be inferred that respondents have a focus on the comfort when passing devices. Respondents are not in favor with issues of environmental or safety yet at present. It reveals a challenge for the government to provide devices that is suitable with the expectation of the users, while at the same time providing devices that people can learn and experience ideal devices.

\subsection{Recommendations and Lesson Learned}

Based on the findings from the field survey and responses from the users, some recommendation can be provided as a way to improve the implementation.

A discussion with the road agency revealed that there is no standard of application process to implement traffic calming. In order to develop a standard, effi- 
cient, and effective implementation, thus a standard process is needed. Hence, the first recommendation is the establishment of a standard request or application process. A small cell can be formed in the City Corporation to inform if someone in the residential area feels that there should be a traffic calming device for safety purpose. A national chain of organization seems as not suitable in developing cities at present, so a cell can serve the purpose to some extent in more efficient way.

Related with the first recommendation, the second recommendation is to develop a standard evaluation, installation, and removal process. If a request is received, then concerned engineer from the City Corporation can pay a visit to the area and evaluate the request of the traffic calming device. Regarding the installation process, a standard and feasible timeline needs to be set and regular repair and maintenance should be done like the road maintenance schedule. Moreover, for removal procedure, some parameters might be needed to be set prior the removal of traffic calming device as a response to the received complaints received from different users.

Furthermore, for future development, it is recommended to employ field data collection to judge the user responses about the existing devices and also to formulate a future guideline for installation. This is the third recommendation. Data obtained both from field survey and questionnaire survey can help to compare the salient aspects of presently constructed traffic calming device with the standard speed hump. The result can be used in future to modify the present dimension and improve the user satisfaction in using the traffic calming device by placing them in the correct location.

In term of institutional matter, the fourth recommendation can also be provided. Steps can be taken so that the problems of traffic calming can be solved by integrating the agency already existing in the country. The agency should be integrated are BRTA (Bangladesh Road Transport Authority), DTCB (Dhaka Transport Coordination Board), MOC (Ministry of Communications), ARI (Accident Research Institute), RHD (Roads and Highway Department); BRRL (Bangladesh Road Research Laboratory), LGED (Local Government Engineering Department).

The fifth recommendation is public education about the measure. Survey shows that most users did not familiar with the dimension of traffic calming (Table 4). Less familiarity exists in local areas. Thus logically, it can be inferred that majority of citizen in Dhaka city are not aware of the pros and cons in using traffic calming. It is also understandable that the city corporation there is a lack of knowledge about the importance of traffic calming device. Thus, as a way to improve the understanding and change the behavior of users, the responsible agency can take steps to educate the community about various aspects of traffic calming devices. From this education it can be expected positive responses from the community, which in the end will improve the effectiveness of the device.

Furthermore, from the engineering point of view, some suggestions can also be provided as presented in Table 6 . In most of the cases, the height of speed 
Table 6. Recommendation in engineering aspects.

\begin{tabular}{|c|c|c|c|}
\hline \multirow{2}{*}{ Dimension } & \multicolumn{2}{|c|}{ Adjustment } & \multirow{2}{*}{ Location } \\
\hline & Reduce & Increase & \\
\hline \multirow{2}{*}{ Height } & $\nabla$ & - & $\begin{array}{l}\text { a) In front of Monipur high school and college, } \\
\text { Shewrapara, Mirpur road }\end{array}$ \\
\hline & - & $\nabla$ & $\begin{array}{l}\text { a) Opposite to mess-A, airport road } \\
\text { b) Opposite to navy head quarter, airport road }\end{array}$ \\
\hline Width & - & $\nabla$ & $\begin{array}{l}\text { a) Opposite to navy headquarter, airport road } \\
\text { b) Opposite to army stadium, airport road } \\
\text { c) In front of kabab ghor, airport road }\end{array}$ \\
\hline Length & - & $\nabla$ & $\begin{array}{l}\text { a) Opposite to navy headquarter, airport road } \\
\text { b) Opposite to army stadium, airport road }\end{array}$ \\
\hline Slope & - & $\nabla$ & In front of Kabab Ghor, Airport Road \\
\hline
\end{tabular}

hump of Dhaka city needs to be reduced, the width needs to be increased, and the slope needs to be milder. On the other side, traffic sign and markings are needed to be installed in all the locations, while regular supervision and a periodical maintenance should be done. It is also important to state that necessary actions should be taken to educate the neighborhood respondents and pedestrians about the significance of speed hump as a means of traffic calming device.

Several lessons can be drawn from the experience in implementing traffic calming in developing city like Dhaka city as follows:

a) Before the implementation of traffic calming, it is needed to have socialization to the community regarding the characteristics, benefits, and impacts. Successful socialization will increase public awareness regarding the measures. This awareness is fundamental for the sustainability of the traffic management scenarios, as it can be expected as a first step to implement another measure.

b) As there is a capacity and capability limitation in developing cities to manage comprehensive and well-designed traffic management measures, thus a local specific measures is needed. Traffic calming devices that is designed and adjusted to be suitable with local characteristics is more preferable, rather than just copied and imported from developed cities. It is understandable to learn from developed cities who have well managed and researched, but adjustment is a must.

c) Setting up a unit to specifically responsible for the development of traffic management measures will be beneficial. This unit will responsible in researching and developing the measures and find a suitable measures with the local context. This unit will maintain the sustainability of the development, rather than hand it to transportation department which is responsible for a very broad matter.

\section{Conclusions}

Questionnaire survey reflects that the respondents are in agreement about the 
suitability of speed hump. Different locations show different degrees of familiarity. Meanwhile, respondents state different opinions when discussing the suitability and quality of speed humps for different road classes.

It is found that respondents have variety of opinion regarding the impact of the implementation of speed hump. Although, the model reveals that the most important feature of speed hump is dimension. It is believed as the main feature influencing the level of comfort when riding passing the device. Thus, an appropriate placement and dimension of the traffic humps is an urgent requirement by implementing an effective and coordinated policy and actions.

Several recommendations can be provided. The recommendations cover from public education from related agency about the characteristics and benefits of traffic calming. This is important as a way to improve the effectiveness of the measures by the change of behavior of users. Further recommendation is the development of standard in evaluation, installment, and removal. Standard dimension and related engineering aspects might be beneficial in improving the effectiveness. For long term recommendation and improvement continuity, a time series data collected from the field as well as the public perception might be beneficial for improving standard from time to time.

Several lessons learned can be gathered from the experience of the implementation in Dhaka City. From the experience of the community in Dhaka, socialization prior to implementation is a must. Public awareness will enhance the acceptance, while it will also increase the possibility of their participation in improving the measures. Furthermore, to maintain its sustainability, then a special unit which is responsible for the development of traffic management is needed. Not just responsible for the improvement, but it may continue the data collection from time to time. This is fundamental as a base to design a measure which is suitable with local context and characteristics.

This study had few major limitations, which can be mentioned as follows. This study confined its focus into traffic hump only as a means of traffic calming device which could be more elaborated considering all the available types of traffic calming devices. It was already chosen least numbers of roads for time constrain to analyze which could be done in a large profile, the number of neighborhood respondents considered in questionnaire survey could be more which would make it more effective. This study considers some major roads out of Dhaka city to give a universal figure to the output of this research.

Further experiments should be carried out on designs with different dimensions. Speed humps with more gradual slopes, sinusoidal humps or speed $\mathrm{cu}-$ shions may be better suited for heavy vehicles. This research can be a first step for future study in developing more suitable guide line to make a more appropriate standard, which is useful for application in Bangladesh as well as for other developing countries.

\section{References}

[1] Highways Department, Government of the People's Republic of Bangladesh, Dhaka. 
National Road Safety Council (NSRC) (2011) National Road Safety Strategy Action Plan (NRSSAP) 2011-2013, Ministry of Communications, Bangladesh Road Transport Authority, Government of The People's Republic of Bangladesh, Dhaka.

[2] Ahmed, I. and Ahmed, B. (2013) Urban Road Accidents in Dhaka, Bangladesh. 16th International Conference: Road Safety on Four Continents, Beijing, 15-17 May 2013.

[3] Pasanen, E. (1993) The Video Recording of Traffic Accidents. Report No. 1993: 4, March 1993, Finland City Planning Department, Helsinki.

[4] Anderson, R.W.G., McLean, A.J., Farmer, M.J.B., Lee, B.H. and Brooks, G.B. (1997) Vehicle Travel Speeds and the Incidence of Fatal Pedestrian Crashes. Accident Analysis and Prevention, 29, 667-674. https://doi.org/10.1016/S0001-4575(97)00036-5

[5] Lockwood, I.M. (1997) ITE Traffic Calming Definition. ITE Journal, 67, 22-24.

[6] Ministry of Communications (2007) Road Management Systems Users Guide, Roads and Highways Department. Government of the People's Republic of Bangladesh, Dhaka.

[7] Department of Public Works City of Sunnyvale (2012) Neighborhood Traffic Calming. Division of Transportation and Traffic, Sunnyvale.

[8] Ewing, R., Brown, S.J., and Hoyt, A. (2005) Traffic Calming Practice Revisited. ITE Journal, 75, 22-28.

[9] City of Sandusky (2003) Traffic Calming Program. City of Sandusky, Ohio.

[10] Webster, D. and Layfield, R. (1998) Urban Traffic Calming Measures-Design, Effectiveness, Public Attitudes and Environmental Issues. PA 3365/98, PTRC Paper at European Transport Conference, London, 179-193.

[11] Rahman, F., Kojima, A. and Kubota, H. (2009) Investigation on North American Traffic Calming Decision Making Process. Journal of the Eastern Asia Society for Transportation Studies, 7, 1437-1452.

[12] Joewono, T.B., Adipratama, D.H., Puar, G.H.P. and Jaganaputra, A. (2011) The Effectiveness of Indonesian Speed Reduction Devices. Proceedings of EASTS Conference, Jeju, 20-23 June 2011, 361

[13] Hydén, C. and Svensson, Å. (2009) Traffic Calming in India: Report on the Theory of Traffic Calming and Empirical Trials in the City of Jaipur. Bulletin 252, Department of Technology and Society, Lund University, Lund.

[14] Rosli, N.S. and Kadar Hamsa, A.A. (2013) Evaluating the Effects of Road Hump on Traffic Volume and Noise Level at Taman Keramat Residential Area, Kuala Lumpur. Journal of the Eastern Asia Society for Transportation Studies, 10, 1171-1188.

[15] James, W.F, Court, T. and Prosi, S. (1999) A Traffic Calming Toolbox-A Technical Resource Developed for the South Western Region of Connecticut. 69th Annual Meeting of ITE, Las Vegas, 1-4 August 1999, 23.

[16] Kojima, A., Kubota, H., Yoshida, M., Ichihara, S. and Yoshida, S. (2011) Effectiveness of Speed Humps Ranged at Different Intervals Considering Roadside Environment Including Vehicle Speed, Noise and Vibration. Journal of the Eastern Asia Society for Transportation Studies, 9, 1913-1924.

[17] Saffel, A.J. (1998) Effective Traffic Calming Applications and Implementation. Minnesota Department of Transportation, Saint Paul, MN.

[18] Departemen Pemukiman Dan Prasarana Wilayah (2004) Pedoman Fasilitas Pengendali Kecepatan Lalu Lintas Direktorat Jenderal Prasarana Wilayah. Jakarta, Indonesia. (In Indonesian) 
[19] Johnson, L.-T. and Nedzesky, A.J. (2004) A Comparative Study of Speed Humps, Speed Slots and Speed Cushions. ITE Annual Meeting Compendium, Institute of Transportation Engineers (ITE), Washington DC.

[20] Kathleen, C. (2003) Summary of Problems Associated with Traffic Calming Devices in the United States. US DOT, Boulder, CO.

[21] Toure, M.A. (2007) Road Safety in Bangladesh-Constraints and Way Forward. BUET, World Bank, Dhaka. 